\begin{tabular}{lr|} 
& $\begin{array}{r}\text { Forum Pedagogiczne } \\
11(2021) 1\end{array}$ \\
$\begin{array}{l}\text { THOlynęło: } 6.12 .2020 \\
\text { THOMAS RUCKER }\end{array}$ \\
$\begin{array}{l}\text { Bern, Switzerland } \\
\text { Zatwierdzono do druku: } 19.03 .2021 \\
\text { DOI: } 10.21697 / \text { fp.2021.1.20 }\end{array}$
\end{tabular}

\title{
THE LOGIC OF MODERN EDUCATION AND THE PRINCIPLE OF CONTROVERSIALITY
}

\begin{abstract}
In recent years, philosophy of education increasingly has been addressing the question of which controversial issues should be taught as controversial in the context of public education. In this article, I will consider this question from an educational point of view; in other words, keeping in mind the specific logic of modern education. On the one hand this enables us to contextualize the debate about the principle of controversiality in terms of educational theory. On the other hand, it grapples with a specific gap in educational descriptions of public education: Although there is support for the principle of controversiality, the question about possible criteria for differentiating between issues that are to be addressed in a directive versus non-directive manner has received little attention up to now. My proposed solution to this problem involves a combination of two criteria, each of which can be justified in relation to the overarching task of modern education - the enablement of Bildung.
\end{abstract}

Keywords: education; logic; controversial issues; public sphere; Bildung.

If we understand education as a practice that aims to introduce children and young people into society, and if we also assume that controversies are typical of life and living together in modern societies, then we may conclude that education also includes the task of introducing newcomers to public controversies. Clearly, this does not tell us which controversies children and young people should be introduced to at all, nor does it answer the question of which controversies should be taught as controversial in the context of public education. In recent years, the latter question in particular has been discussed intensively in the philosophy of education (see for example Hand 2008; Cooling 2012; Gregory 2014; Warnick,

* Thomas Rucker - PD Dr. phil., Lecturer for Foundations of Educational Science at the University of Bern, Switzerland; Mailing address: University of Bern, Institute of Educational Science, Fabrikstrasse 8, 3012 Bern, Switzerland, e-mail: thomas.rucker@edu.unibe.ch. 
Smith 2014; Hess, McAvoy 2015; Tillson 2017; Zimmerman, Robertson 2017; Yacek 2018; Saetra 2019). In this context, it is correctly noted that it makes a difference whether one uses, for example, a behavioral, political, or epistemic criterion to differentiate between issues that should be taught as settled and issues that should be taught as controversial. It is simply a different matter to claim that a question should be addressed as controversial if it is discussed controversially in the public sphere, if this question cannot be answered in relation to the values of a liberal democratic society, or if it is the subject of reasonable disagreement. Each of these proposals refers to specific presuppositions, entails specific burdens of justification, and leads to different conclusions in assessing specific issues (evolution, migration, euthanasia, homosexuality, climate change etc.).

There is as yet no generally accepted answer to the question of which criterion should be used to designate those subjects that should be taught as controversial in the context of public education. To put it bluntly: The controversy over the principle of controversiality itself has the form of an open debate. In addition, it is worth noting that, in this debate, hardly any attempts have been made to deal with the problem from an educational point of view. This can be seen in the fact that none of the relevant contributions to the topic starts from a theory of education that attempts to clarify what is meant by education. Instead, there is a tendency to accept what education "is" or what the term education means, as more or less given. It is of no use here to refer to events in certain institutions that we usually call "educational," because here, too, we would have to ask how - for example in the context of schools - we can differentiate between education and alternative forms of interaction. In other words in order to determine whether education is taking place, we need a concept of education - such a concept is developed and justified within a theory of education. In this sense, education is not simply given, but is constituted as an object of inquiry within the specific perspective of an observer. This makes it clear that it is important - if only for the sake of methodological control - to introduce an educational perspective into the debate about the principle of controversiality in public education. The fact that this has not happened to the necessary degree may have to do with the specific configuration of the context in which (public) education is usually addressed in the English-speaking world, which is vastly different from that which characterizes the German-speaking context (see Bellmann 2014, pp. 278f.).

In the English-speaking world it is typical for education to function as an object within a multidisciplinary field. The discourse on education is found in connection with disciplines that are traditionally termed "educational studies." The central perspectives on education include those of philosophical, sociological, psychological and historical inquiry. Importantly, these perspectives are conceived as applied philosophy, sociology, psychology or history, so that education - while addressed from a philosophical, sociological, psychological and historical perspective - is not addressed from an educational point of view. For someone in the multidisciplinary 
field of educational studies, this reference to an original educational way of thinking may be irritating, since in this context the possibility of asking educational questions about education is sometimes explicitly rejected: "There is no distinctively 'educational' way of thinking” (Tibble 1971, p. 16). Anyone familiar with the continental European and in particular German-speaking tradition of educational theory might, on the other hand, find it more than surprising that education is not at the very least also considered from an educational perspective - one in which the question of what education "is" is asked in the first place, and in which the attempt is made to describe education in the light of a specific educational normativity (see Benner 2019). The latter can be seen, for example, in the fact that education from an educational point of view is traditionally not reduced to the introduction of children and young people to cultural content (knowledge, skills, values, norms etc.), but rather is described as a form of interaction "in which the freedom of the new generation is at stake" (Biesta 2020b, p. 1024). The assumption that there is an educational perspective on education that cannot be reduced to other perspectives, does not derive from them, and also cannot be replaced by them, is, of course, not linked to the assertion that there is no disagreement on how the educational perspective can be determined in detail and - accordingly - how education can be described from that perspective. However, it makes a difference whether or not the educational perspective plays any role in the academic study of education.

This also applies to the question which issues should be addressed as controversial in the context of public education. In my article, therefore, I would like to explore this question, deliberately taking into account the specific logic of modern education. As I will try to show, this account opens up the possibility for theoretical progress in at least two ways: On the one hand it is possible to contextualize the debate about the principle of controversiality in public education in terms of educational theory, and at the very least to supplement the philosophical approach with an educational one. On the other hand, this paper also grapples with a gap in educational descriptions of public education, where the principle of controversiality may be favored but where the associated problem of criteria has so far received little attention.

I will begin by explaining the specific logic of modern education in terms of the principles of Bildsamkeit, self-determination and the summoning to self-action. This sets the framework for the considerations that follow. Then I will reconstruct how the principle of controversiality in public education has been discussed from an educational perspective up to now. I will argue that the question of which criteria can be used to determine those controversial issues that should be taught as controversial has so far been sorely neglected. Finally, I would like to present my own proposal for a solution to the problem. In doing so, I will try in particular to show that the combination of two criteria that I propose can be justified with regard to the overarching task of modern education - the enablement of Bildung. 


\section{Modern education as non-affirmative education}

Which issues should be taught as controversial in the context of public education? In order to answer this question from an educational point of view, I will first clarify the basic structure of modern education. By modern education, I mean a specific understanding of education, whose development is irreducibly bound together with the process of social transformation that took place in Europe, mainly from 1700 to 1850 , in which people began to understand themselves as free and equal, bound to one another in solidarity. The concept of mutual respect between people as human beings becomes a central point of orientation in this process, which we describe today as the modernization of western societies - also in educational thinking (see Brüggen 1997, pp. 115ff.). Seen from a systematic point of view, this period marked a turning point beyond which education can now be understood in both an affirmative and a non-affirmative sense, whereby the latter stands at the center of the following considerations. In short, when we discuss in the following text the logic of modern education, my main concern is with clarifying the specific logic of non-affirmative education.

Descriptions of education as an affirmative or a non-affirmative practice share the assumption that education is a form of interaction that is constitutive of human life and co-existence. Education is understood as a practice that responds to a specific and persistent human condition: the fact that we are born into a society and have to be introduced into it. Conversely, education fulfills the function of ensuring that a history of living together that has already begun can be continued by the next generation (see Sünkel 2013).

Unlike the description of education as affirmative - in which education is reduced to a means of enforcing social expectations of the next generation - a description of non-affirmative education focuses on education as a traditional and transforming intergenerational practice (see Benner 1988/1990). In this context, the question of what is to be favored or disfavored in living and in living together is understood as one that has not already been answered in human history, so that education would only have to pass on answers that have already been found. Rather, nonaffirmative education hands over the aforementioned question as a question. This includes helping newcomers to reflect on answers that others have already found in their search for orientation. But these answers do not provide a standard to which education would have to be oriented. Rather, they become the object of discussion in education itself - which of course implies that children and young people may transform tradition in their own way (on the international reception of a theory of non-affirmative education see Uljens, Klimaki 2017).

Given this background, to describe education as non-affirmative can be interpreted as an attempt to define an education in which the newcomers' thinking, judging and acting are not standardized. It is precisely in this regard that such an understanding of education itself proves to be non-neutral. Rather, it expresses 
a normative position that is specifically directed against attempts to instrumentalize education for the implementation of extra-educational purposes. Modern education in the non-affirmative sense takes its starting point by social expectations addressed to the next generation, but it does not affirm these expectations. Rather, it treats them as cultural objects generated by people; objects that - since people are imperfect living beings - can eventually be reconsidered as points of departure for the future interplay between the individual and the world. The specific task of non-affirmative education, traditionally referred to as Bildung, is that children and young people be drawn into this interplay and helped in relating to "external" demands. Accordingly, modern education can also be described as the enabling of Bildung - and thus as a form of interaction that does not only consists of introducing newcomers to culture, but rather addresses them in a specific sense as subjects - that is, offers them the opportunity to examine claims to validity (see Rucker 202ob, pp. 56ff.).

Here I would like to take a closer look at the logic of modern education. I do so by distinguishing three principles of a non-affirmative education, namely selfdetermination, the summoning to self-action and Bildsamkeit.

Linking education to the task of releasing the individual for a life of selfdetermination must not be misunderstood in a relativistic way. Rather, the development of one's own positions, to which non-affirmative education calls for, presupposes "working through" the different experiences that arise in the confrontation of the newcomer with the resistant world. However, education as a means of enabling Bildung does not only involve confronting the individual with a resistant world and helping him or her to work through experiences of difference. Instead, Bildung also implies that the individual "brings him- or herself into play as a judging and acting subject with respect to his or her own culture" (Brüggen 1999, p. 60). With that in mind, non-affirmative education involves opening up the possibility for the individual to relate him- or herself to the world - particularly given the world's resistance - as well as to expose his or her own positioning to potential experiences of difference (e.g. in the confrontation with alternatives) in order to find positions that "coordinate," so to speak, with the resistance of the world.

This definition of the task of education correlates with a specific form of the educator's interaction with children and young people. The term used to describe this form, in the context of a theory of non-affirmative education, is the "summoning to self-action." This term brings modern education into focus as a form of interaction in which newcomers are confronted with a resistant world, a world whose demands on the individual could be said to shake his or her self-reference. Summoning to self-action also means helping the individual to work through experiences of resistance - but in such a way that the individual is given the opportunity to relate to the respective demand, i.e. to bring him- or herself into play.

At this point, Gert Biesta has suggested a difference that I find lends even more contour to the concept of summoning to self-action: Since non-affirmative 
education should not be mistaken for an invitation to children and young people to articulate their "own" opinions and in this sense to "self-action," Biesta prefers to differentiate between the call to "Be yourself!" and the call to "Be a self!" $\mathrm{He}$ considers the latter kind of summoning to be of educational value (see Biesta 2020a, pp. 1018ff.). In the context of a theory of non-affirmative education, the call for self-action is understood in the sense of "Be a self!" - namely, not as a call to show who you are, but rather a call to show how you position yourself vis-à-vis an object as you work through an experience of difference. While the first case addresses a person's identity, the second case is about addressing the newcomer as a subject.

A description of education in which it is understood as a call to self-action, is based in any case on a specific anthropological premise: that the individual can work through experiences of difference, and in this sense become someone else - for whom the world will also appear differently in the future. In the theory of nonaffirmative education, this assumption is designated as the principle of Bildsamkeit (see Anhalt 1999). Without the prerequisite that the human being is bildsam - that is, that we are not determined by nature and at the same time capable of developing new abilities through self-thinking, self-judgment and self-action - it would make no sense to understand education in a non-affirmative sense at all. And conversely, the individual is always assumed to be bildsam when addressed as a subject.

In this context, to understand the individual as bildsam does not only mean to assume that he or she is responsive to education. Nor does it only mean that the individual is to be seen as someone who can develop his or her own positions visà-vis a resistant world. Beyond these aspects, Bildsamkeit refers to the individual's capacity to understand him- or herself as a subject. Non-affirmative education is also, and above all, oriented towards addressing this aspect of Bildsamkeit, enabling the individual to experience his ability to bring him- or herself into play when dealing with a resistant world. In other words: To summon the individual to selfaction and to bring him into, for example, a situation of having to choose between options, should not only make the individual decide but also make him or her aware of the option to see him- or herself as the one who chooses. It is important to emphasize this point, because the experience of being able to be a subject may be a prerequisite for individuals to begin to relate to the world on their own initiative, thus making further education superfluous.

\section{Public education, controversial issues and the criterion problem}

The development of a modern understanding of education and the clarification of its constitutive principles must, as mentioned, be seen against the background of the fundamental social transformation processes that took place in Europe, particularly between 1700 and 1850 . This was the period when societies started becoming modern, which in this context refers to a process of social differentiation. Today, modern societies describe themselves as complex societies that are differentiated 
into various contexts, each of which functions according to its own logic. These contexts - whether science, politics, religion, art, economy, law or morality - offer their own specific perspectives on issues of the day (see Luhmann 2012, 2013). Seen in this light, we might expect a description of modern education as non-affirmative to be "sensitive" to the fact that growing up in modern societies takes place under the conditions of a plurality of perspectives - perspectives that may or may not be in harmony, and may also contradict each other. Moreover, it must be clear that controversies do not only appear between different social areas, but also within them. Controversies are found not only between morality, politics, religion or science, but also between various moral, political, religious or scientific positions. This inevitably raises the question of how to react - from an educational point of view - to the fact that certain issues are discussed controversially in modern democratic societies.

If one sees education as one of many social contexts, then one may ask how the relationships between these contexts can be determined in such a way that the different areas can actually function according to their own logic. It should be clear that the likelihood of a non-affirmative education depends to a large extent on the fact that the other areas of society refrain from taking education into their service. This condition applies along the same lines to all areas of society. If each area is to operate according to its own logic, then the various contexts must categorically refrain from granting one area primacy over the others. In the theory of nonaffirmative education this imperative is called the principle of non-hierarchicality (see Benner 2015, pp. 118ff.).

This principle of a non-hierarchical order of social contexts not only requires that education must not be instrumentalized for external purposes. Education itself - and this is decisive - must submit to the principle of non-hierarchicality; in other words, education may not claim primacy over other social areas. If there is conflict within science, politics, religion, morality or between different social contexts, then - so it seems - it cannot be the task of education to resolve any individual conflict by favoring one particular side. An education that decides controversies in this sense would thus - one might think - claim primacy for itself - something that education must deny to other areas in order to operate according to its own logic. Such a violation of the principle of non-hierarchicality can - as the argument could go - only be avoided if newcomers are not steered to certain positions in the case of public controversies, but rather are drawn into these conflicts. In short: Apparently, in education, a principle of controversiality derives directly from the principle of non-hierarchicality.

In the third section of my article I will show that such a conclusion would be premature. It would mean overlooking the fact that there are good reasons not to treat all public controversies as equal, and to teach only certain issues that are controversially discussed in society as controversial in the context of public education - especially when referring to the logic of modern education. Here, I am 
only concerned with pointing out that a description of modern education as nonaffirmative actually requires paying attention to the questions raised by the principle of controversiality. This is why it is surprising that, at this point, the question of how to deal with the fact that many issues are discussed controversially in modern societies has only been explored to a limited extent within the framework of a theory of non-affirmative education. In particular, very little attention has been given as yet to the question of which issues should be taught as controversial in the context of public education. This question is usually answered with a reference to the socalled Beutelsbacher Consensus ${ }^{10}$, in which, among other things, the imperative is so formulated that current issues that are discussed controversially in politics and science should also be addressed as controversial in education - at least in the context of public education. Benner, for example, suggests that the demand that teaching "must also grapple with plural and controversially discussed issues in a plural and controversial manner" is not restricted to civic education or natural science subjects, but "can also be applied to other subjects in the school curriculum" (Benner 2018, p. 155). After all, in modern democratic societies, controversies are not only found in political and scientific matters, but also in moral, religious or economic questions. Whatever the category, it is not the task of public education to "lead students to a firm position on controversial issues, but rather to give them insight into conflicting positions and to initiate processes of developing one's own judgment, expressly without leading them to a specific conclusion" (ibid., pp. 155f.). In short: Students should be introduced to different positions when dealing with public controversies, so that they understand these positions and can develop their own judgments, without being forced to take a definitive position. The process of developing one's own judgment should rather be kept open for Bildung processes beyond education, in which positions - once taken - can be reexamined, questioned again, and even changed.

Michael Hand describes education in this sense as non-directive and distinguishes it from directive education: "To teach a claim directively is to teach it with the intention of persuading students of its truth or falsity; to teach a claim nondirectively is to teach it with the intention of not so persuading them" (Hand 2014, p. 425). Directive education can be recognized by the fact that a subject is addressed with the intention of persuading others. This means that an issue is presented as settled. The educator tries to lead the student to the one correct answer; the person to be

10 The Beutelsbacher Consensus is named after a conference site where the then-leading theorists of civic education in the German-speaking world met in 1976. It still marks an important break in the theory of civic education. The Consensus was not an official decision of the conference, but rather an impression of the conference formulated retrospectively by participant Hans-Georg Wehling. In his view, what the representatives of different didactical positions were able to agree on as the principles of civic education in modern democratic societies were in particular a prohibition against overwhelming the student - sometimes also called a prohibition against indoctrination - and the principle of controversiality (see Wehling 1977, p. 179). 
educated is to accept the only correct position. Non-directive education, on the other hand, means addressing a subject without any intention of persuasion. In other words, the content is taught as open to debate. The educator tries to introduce children and young people to a controversy about the right answer to a particular question. The different positions considered in this context should be treated as neutrally as possible. The person to be educated should understand the various positions and their justifications, as well as develop his or her own position in light of the conflicting alternatives and be able to defend that position against objections (see Hand 2008, p. 213).

The difference between directive and non-directive education can be freely combined with the distinction between theoretical and practical issues. This is evident from the simple fact that not only practical problems - those whose answers demand a value judgment - are controversially discussed in the public sphere. Value judgments are neither a necessary nor a sufficient condition for public controversies. For example, in paleontology there is still a lively debate about what caused the mass extinction of the dinosaurs. In mathematics, there is still disagreement over the assumption that every even number is the sum of two prime numbers. On the other hand, there are practical questions for which there is a clearly established "correct" answer. For example, it should be undisputed that Caspar David Friedrich could create works of art more beautiful than the author of this text (and perhaps also the reader) could. Similarly, there would be no disagreement with the statement that it is morally wrong to trick an elderly woman to enter one's home in order to murder her and then use her money to go to the cinema (see Lobkowicz 2003, p. 367). Being freely combinable means that theoretical questions are not always about issues that should be taught directively, and practical questions are not always about issues that should be discussed non-directively. Rather, theoretical and practical issues can be addressed both directively and non-directively.

The question thus arises as to which criteria should be used to decide which issues should be taught in a directive or non-directive manner. Benner's position that public education must deal with controversial issues in a controversial manner is only plausible at first glance. True, information is provided here about what it means to address a controversial issue in a non-directive way. But it remains unclear whether the position of addressing all controversial issues as controversial in the context of public education is actually supported here, or whether criteria are used implicitly to restrict the range of relevant issues.

At this point I would like to emphasize that by favoring a principle of controversiality for public education, one inevitably takes a stand on the criteria that should be used to distinguish between issues that are addressed in a directive versus in a non-directive manner. Arguing for a principle of controversiality is necessarily linked to the question of corresponding criteria. Even the explicit renunciation of such a criterion is tantamount to claiming a criterion: namely that all controversial issues should also be addressed as controversial. But that also means that certain 
criteria are always taken into consideration whenever someone argues in favor of a principle of controversiality. The failure to take this fact into account is the "blind spot" linked to the principle of controversiality in the context of a theory of nonaffirmative education. This undermines the demand of a modern understanding of Wissenschaft, namely to structure the presuppositions of our descriptions of education as rationally as possible. There is thus a risk of accepting criteria without subjecting them to critical examination. This kind of deficit can only be corrected by explaining criteria and discussing their advantages and disadvantages. However, it cannot be assumed that known criteria, as developed in philosophy of education, can be integrated into a description of non-affirmative education without difficulty. Rather, it might be necessary to deal with the problem independently in light of the reconstructed logic of modern education, in other words to develop an educational proposal for a justified criterion or criteria.

\section{The principle of controversiality - an educational approach}

My proposal provides for a combination of two criteria, each of which can be justified by the specific logic of modern education. Only those issues should be addressed as controversial in the context of public education in which, firstly, positions that accept a specific value orientation conflict with each other and, secondly, in which there is no overriding rule of judgment that would allow a position to be designated as the sole correct one. Below we will take a closer look at these combined criteria.

Non-affirmative education is oriented towards enabling Bildung. Knowing this, it would be absurd, on the one hand, to argue for supporting newcomers to form their own judgments while at the same time treating as equal - or worthy of discussion - those positions whose normative orientation is incompatible with that of education that aims to enable Bildung. In other words, if one agrees that non-affirmative education is based on specific normative premises, then one understands that it would ultimately undermine these premises if one actually taught every controversial issue in society as controversial. One would then have to answer the question of why one favors education as enabling Bildung at all, if at the same time one is willing to relativize the normative claim associated with it that each individual is to be considered and treated as an end in itself - by giving equal considerations to positions that are incompatible with this orientation. Seen in this light, not only does the principle of controversiality demand that certain public controversies be taught as controversial in the context of education but also demands that certain positions in this context be either left out or exposed to criticism.

This position is further substantiated if one considers not only the normative premise of education as the enabling of Bildung, but also the fact that Bildung processes themselves are normatively limited in specific respects. As I have tried to make it clear, Bildung refers to the process in which the individual develops the 
ability to lead a self-determined life. Self-determination must not be misunderstood - and this is a key thought here - in an individualistic way. Rather, it is linked to the demand that the individual develops the ability and willingness to grant freedom to all other people as well, or to enable them first and foremost to selfdetermine their own lives (vgl. Rucker 2019, pp. 649ff.). If one assumes that Bildung means the development of the ability to self-determination, and furthermore if one assumes that one needs space in order to lead such a self-determined life something one cannot merely count on in the interaction between people but that must be established and stabilized - one should understand that Bildung cannot be described solely as the development of the ability to lead a self-determined life. Bildung must also be understood as the development of the ability and the willingness to grant others the freedom to lead a self-determined life or to enable this in the first place - at least if the development of the ability to self-determination is understood as an aspiration to which all people are entitled.

If you do not rush to define the freedom that education is supposed to offer as "neo-liberal freedom," but rather as "democratic freedom" (Biesta 2017, p. 79), you can also - given this background - argue for a specific interpretation of the principle of controversiality in public education. It would be no less absurd if Bildung implied the development of an attitude to treat other people as "ends in themselves," while at the same time - in the context of public education - treating positions that deny people equal freedom to find, live out and further develop their own positions as legitimate.

The question arises whether, in the context of a theory of non-affirmative education, one should further limit the spectrum of issues that should be taught in a non-directive manner. Let us first examine some controversies that, in the context of this theoretical approach, are supposed to be discussed as open-ended. Among them are, firstly, controversies between political positions in which the interests of preserving society collide with the interests of changing society ${ }^{11}$ (see Benner, Stepkowski 2012, pp. 68ff.); secondly, conflicts between scientific paradigms that operate with different methodological guiding questions and subsequently - produce different forms of knowledge (see Benner 2020, pp. $76 \mathrm{ff}$.); and thirdly, conflicts between different social contexts such as politics, science, religion, morality, art, business and education, each of which follows its own logic (see Benner 2015, p. 187).

Are there similarities between these different kinds of conflicts? I think one similarity might be that in none of them there is an overriding rule that could justify - in a generally binding way - the preference of one position over all remaining options. Instead, it is always possible to confront a position with alternatives for

11 As we can now add, the conflicting positions must reveal a commitment to the democratic values of freedom, equality and solidarity. 
which there are also good reasons, without there being one best reason available that could justify someone's decision.

In order to better grasp the nature of such controversies, I find it helpful to consider the distinction between simplicity, complicatedness and complexity as introduced in complexity theory (see Rucker, Anhalt 2017, pp. 23ff.). Simple and complicated problems differ from complex problems in offering known rules to solve a given problem successfully. When it comes to simple problems, the rules required to solve them can be applied without any interference. But to solve complicated problems, it is generally not possible to apply rules without interference, perhaps because people do not know those rules. In other words, a certain problem that appears simple to experts may seem complicated to a layperson. Complex problems, on the other hand, are characterized by the fact that there are no known rules that would allow anyone - even experts, and this is important - to solve a problem definitively.

If one works with the difference between simplicity, complicatedness and complexity, one can distinguish between different kinds of controversies: those that can be resolved by referring to an overriding rule to determine which answer to a particular question is correct, versus those in which different positions collide and there is no possibility to refer to an applicable rule. The latter type proves irreducible in a specific sense. When it comes to complex problems, there is no universal answer to the question of what the only correct position is to take on an issue. And conversely, it means that we have to grapple with different positions, each of which may be justified. ${ }^{12}$

Given the difference between simple, complicated and complex problems, it is possible to define more precisely the criterion that seems to play an implicit role in the theory of non-affirmative education in order to differentiate between issues that one should address directively and those that one should address nondirectively. According to this criterion, one should address complex problems as non-directive, whereas those that are merely complicated should be taught as directive. Any controversies that are also observable in complicated issues can certainly be taken up in education - but not in such a way as to place the conflicting positions on an equal footing. In the case of complicated questions, non-affirmative education is not oriented towards summoning newcomers to develop their own

12 At this point the considerations are unmistakably close to what is discussed in the context of philosophy of education as the epistemic criterion: This criterion states that in the context of public education only those issues should be taught as controversial that are the subject of reasonable disagreement, i.e. controversies whose resolution cannot be based on the only correct answer to a question (see Hand 2008). 
judgments, but rather aims at supporting an individual in gaining insight into the correct answer to a question. ${ }^{13}$

The fact that a theory of non-affirmative education seems to refer to complex problems in order to specify the principle of controversiality does not yet indicate whether - or even how - such a criterion can be justified in this context. Finally, I will zero in on this question, in an effort to show that it would be equally problematic to address open questions as settled and settled questions as open.

A type of education that treats issues as settled despite the fact that there are alternative, justified positions available is incompatible with the task of nonaffirmative education to enable Bildung. In this case, education cannot be carried out consistently as a call to self-action. When it comes to complex problems, since no position can offer an argument that has decisive rational force, such education would have to resort to methods and means that prevent the individual from appearing as a subject, in order to make him or her consider a certain position to be justified (concealing alternatives, presenting positions in a "distorted" manner, persuading a person to adopt a position by means of sympathy etc.). However, Bildung specifically eschews committing oneself to positions in such a manner that requires the suspension of self-action. In order to enable Bildung, the educator must not decide controversies in which different, equally justifiable positions may be adopted. Rather, the educator should help children and young people "to find and follow their own path" (Ballauff 1993, p. 4).

Similarly, an education that treats issues as open despite the fact that one position is superior to all the others also undermines the aim of preparing an individual for a self-determined life. On the one hand, there is a danger that newcomers would adopt false opinions, and on the other hand, there is a risk that they might believe that there is no preferable answer to the question at hand. In both cases, the significance of an already achieved level of knowledge - a "historically achieved level of thought" (ibid., p. 5) - integral to an education that enables Bildung is undermined. The individual should be released to determine him- or herself in relation to the world. We define knowledge as descriptions that have passed the test of critical examination over time, so that we currently have no reason to question their validity. An education with a non-directive orientation, despite addressesing issues that could be considered settled, risks at the very least "removing" children and young people from the real world and contributing to living their lives in a web of deception. This would not only be problematic from a moral point of view, as it could cause considerable harm to the newcomers ("I didn't know that smoking increased the risk of lung cancer!"). It would also undermine a claim traditionally associated with the concept of Bildung: that education should help children and young people to develop the ability to take positions based on objective

13 The question of how simple issues should be addressed is superfluous, because in this case there is no need for education, or education has already come to its end. 
insights. Clearly, Bildung does not mean to become entangled in deception. From an educational point of view, the educator must aim to persuade newcomers that a certain position is correct, if it is the only one for which good reasons can be given today.

Ultimately, the questions arise: Might the proposal developed here conflict with the principle of non-hierarchicality? Does this principle not mean that public disputes must not be settled through the means of education? Is education accorded undue primacy here?

Regarding the criteria I have suggested, the first objection could in fact be that education is not entitled to resolve public controversies in relation to certain normative premises. The choice of one's way of life should not be predetermined in the context of public education. It is possible to counter such an objection by arguing that the objection itself represents a normative claim: That is, public education must keep the possibility open of determining one's own way of life. But that is exactly what the claim of Bildung is about. It would be unreasonable to refer to the idea of self-determination to give equal weight to positions that reject this very idea.

The second objection could be that education is not entitled to resolve controversies relational to the claim that only reasonable differences of opinion should be taught as controversial. This objection can be countered by the argument that education would only claim primacy when attempting to resolve controversies in which no position could claim primacy. On the other hand, in all those cases the position to be favored or deferred is clear - precisely because an overriding rule of judgment is available - education does not violate the principle of non-hierarchicality. For the hierarchical order of positions is not brought about by education; rather, it is a "given," and education simply serves the function of confronting newcomers with this reality.

The principle of non-hierarchicality thus proves fully compatible with the proposed combination of criteria. It does not require that all issues discussed controversially in the public sphere be addressed in the context of public education as if the answer to the question at hand had not already been determined. In the context of public education, only questions should be taught non-directively, when conflicting positions are compatible with the idea of mutual respect for human freedom; and in addition, when no overriding rule is known that would rank the respective positions according to the only "correct" order. A future task will be to relate this combination of criteria to alternative proposals. Another challenge will be to defend the position that education should be oriented towards enabling Bildung in the first place, since such an orientation is itself no longer self-evident today (see Rucker 2020a). 


\section{Bibligraphy}

Anhalt E. (1999). Bildsamkeit und Selbstorganisation Johann Friedrich Herbarts Konzept der Bildsamkeit als Grundlage einer pädagogischen Theorie der Selbstorganisation organismischer Aktivität. Weinheim: Deutscher Studienverlag.

Ballauff Th. (1993). Über die Unerlässlichkeit der Bildung. W: Deutsche Gegenwartspädagogik. Borelli M. (red.). Baltmannsweiler: Schneider, s. 1-19.

Bellmann J. (2014). Educational Theory, Nature of. W: Encyclopedia of Educational Theory. Phillips D.C. (red.). Los Angeles: Sage Publications, s. 273-280.

Benner D. (1988/1990). A Non-Affirmative Theory of Education: Its Fundamental Questions and Approach. W: Education A Biannual Collection of Recent German Contributions to the Field of Educational Research, nr 42, s. 91-105.

Benner D. (2015). Allgemeine Pädagogik Eine systematisch-problemgeschichtliche Einführung in die Grundstruktur pädagogischen Denkens und Handelns. Weinheim-Basel: Beltz Juventa.

Benner D. (2018). Religion im Kontext öffentlicher Bildung und Erziehung. W: Bildung in der postsäkularen Gesellschaft. Müller S., Sander W. (red.). Weinheim and Basel: Beltz Juventa, s. 144-162.

Benner D. (2019). Über die eigenlogische Normativität der Erziehung und ihre Bezüge $z u$ anderen Normativitätsansprüchen. „Vierteljahresschrift für wissenschaftliche Pädagogik", nr 3, s. 317-332.

Benner D. (2020). Umriss der allgemeinen Wissenschaftsdidaktik Grundlagen und Orientierungen für Lehrerbildung, Unterricht und Forschung. Weinheim-Basel: Beltz Juventa.

Benner D., Stepkowski D. (2012). Warum Erziehung in Demokratien nicht politisch fundiert werden kann. W: Erziehung und Bildung in politischen Systemen. Anhalt E., Stepkowski D. (red.). Jena: Garamond, s. 49-71.

Biesta G.J.J. (2017). The Rediscovery of Teaching. New York-London: Routledge.

Biesta G.J.J. (2020a). Can the prevailing description of educational reality be considered complete? On the Parks-Eichmann paradox, spooky action at a distance, and a missing dimension in the theory of education. „Policy Futures in Education”, nr 4, s. 1011-1025.

Biesta G.J.J. (2020b). What constitutes the good of education? Reflections on the possibility of educational critique. „Educational Philosophy and Theory”, nr 10, s. $1023-1027$.

Brüggen F. (1997). Bildsamkeit und Mündigkeit des Subjekts Bildungsgeschichtliche und bildungstheoretische Überlegungen zu einer (nicht nur) pädagogischen Idee. „Franz Fischer Jahrbuch für Philosophie und Pädagogik”, nr 3, s. 111-125.

Brüggen F. (1999). Bildung als Orientierungsform Bemerkungen zur Stellung der Bildung zwischen Ethik und Wissenschaft. W: Verführung in orientierungsloser Zeit. Wenger-Hadwig A. (red.). Innsbruck-Wien: Tyrolia, s. 43-66. 
Cooling T. (2012). What is a Controversial Issue? Implications for the Treatment of Religious Beliefs in Education. „Journal of Beliefs and Values”, $\mathrm{nr}$ 2, s. 169-181.

Gregory M.R. (2014). The Procedurally Directive Approach to Teaching Controversial Issues. „Educational Theory”, nr 6, s. 627-649.

Hand M. (2008). What Should We Teach As Controversial? A Defense of the Epistemic Criterion. „Educational Theory”, $\mathrm{nr}$ 2, s. 213-228.

Hand M. (2014). Afterwords: Response to Warnick and Smith. „Educational Theory”, nr 4, s. 425-426.

Hess D. E., McAvoy P. (2014). The Political Classroom: Evidence and Ethics in Democratic Education. New York: Routledge.

Lobkowicz N. (2003). Über Werte. „Studies in East European Thought”, nr 4, s. $367-386$.

Luhmann N. (2012). Theory of Society, vol 1. Stanford: Stanford University Press.

Luhmann N. (2013). Theory of Society, vol 2. Stanford: Stanford University Press.

Rucker Th. (2019). Erziehender Unterricht, Bildung und das Problem der Rechtfertigung. „Zeitschrift für Erziehungswissenschaft”, nr 3, s. 647-663.

Rucker Th. (2020a). Der oblique Blick Öffentliche Erziehung, Nichtaffirmativität und die Herausforderung des Pluralismus. „Jahrbuch für Allgemeine Didaktik”, s. 71-88.

Rucker Th. (2020b). Teaching and the Claim of Bildung: The View from General Didactics. „Studies in Philosophy and Education”, nr 1, s. 51-69.

Rucker Th., Anhalt E. (2017). Perspektivität und Dynamik Studien zur erziehungswissenschaftlichen Komplexitätsforschung. Weilerswist: Velbrück.

Saetra E. (2019). Teaching Controversial Issues: A Pragmatic View of the Criterion Debate. "Journal of Philosophy of Edcation", nr 2, s. 323-339.

Sünkel W. (2013). Erziehungsbegriff und Erziehungsverhältnis Allgemeine Theorie der Erziehung. Weinheim-Basel: Beltz Juventa.

Tibble J.W. (1971). The Development of the Study of Education. W: An introduction to the study of education. Tibble J.W. (red.). London: Routledge and Kegan Paul, s. $5-17$.

Tillson J. (2017). When to Teach for Belief: A Tempered Defense of the Epistemic Criterion. „Educational Theory”, nr 2, s. 173-191.

Uljens M., Ylimaki R.M. (2017). Non-affirmative Theory of Education as A Foundation for Curriculum Studies, Didaktik and Educational Leadership. W: Bridging Educational Leadership, Curriculum Theory and Didaktik Nonaffirmative Theory of Education. Uljens M., Ylimaki R.M. (red.). Dordrecht: Springer, s. 3-145.

Warnick B.R., Spencer Smith D. (2014). The Controversy over Controversies: A Plea for Flexibility and for "Soft-directive” Teaching. „Educational Theory”, nr 3, s. 227-244.

Wehling H.-G. (1977). Konsens à la Beutelsbach? W: Das Konsensproblem in der politischen Bildung. Schiele S., Schneider H. (red.). Stuttgart: Klett, s. 173-184. 
Yacek D. (2018). Thinking Controversially: The Psychological Condition for Teaching

Controversial Issues. „Journal of Philosophy of Education”, $\mathrm{nr}$ 1, s. 71-86.

Zimmerman J., Robertson E. (2017). The Case for Contention Teaching Controversial

Issues in American Schools. Chicago-London: University of Chicago Press.

\section{LOGIKA NOWOCZESNEJ EDUKACJI I ZASADA KONTROWERSYJNOŚCI}

Streszczenie: $\mathrm{W}$ ostatnich latach filozofia edukacji coraz śmielej zadaje pytanie, jakich zagadnienień należy nauczać jako kontrowersyjnych w kontekście edukacji publicznej. W tym artykule spróbujemy odpowiedzieć na to pytanie z edukacyjnego punktu widzenia; innymi słowy, mając na uwadze specyficzną logikę nowoczesnej edukacji. Z jednej strony pozwala to na kontekstualizację debaty na temat zasady kontrowersyjności w ujęciu teorii edukacji. Z drugiej strony chodzi o określoną przestrzeń w edukacyjnych opisach edukacji publicznej. Chociaż istnieje poparcie dla zasady kontrowersyjności, pytaniu o możliwe kryteria rozróżnienia między kwestiami, jakie mają być poruszone w sposób dyrektywny, jakie w sposób niedyrektywny, do tej pory nie poświęcano wiele uwagi. Zaproponowane przeze mnie rozwiązanie tego problemu polega na połączeniu dwóch kryteriów, z których każde może być uzasadnione w odniesieniu do nadrzędnego zadania nowoczesnej edukacji - wzmocnienia wychowania.

Słowa kluczowe: kształcenie, logika, zagadnienia kontrowersyjne, obszar publiczny, wychowanie. 